\title{
Finding of toxicity of herbal shampoo to plant seedlings: phytotest of mixture product that contains membranotropic chemicals as components
}

\section{Utvrđivanje toksičnosti biljnog šampona za biljne sadnica: fitotest mešavine koji sadrži membranotropne hemikalije kao komponente}

\author{
Xiang Cai ${ }^{1,2}$, Sergei A. Ostroumov ${ }^{1,2}$ \\ ${ }^{1}$ Lomonosov Moscow State University, Faculty of Biology, Moscow 119991, Russian Federation \\ 2Shenzhen MSU-BIT University, No 299, Ruyi Road, Shenzhen, Guangdong, P.R. China
}

Rad primljen: 05.01.2021, Rad prihvaćen: 27.02.2021.

\begin{abstract}
Results of research of effects of a chemical product which contains synthetic surfactants on plant seedlings are presented. The chemical product studied was a shampoo made in China, namely, Ginger Polygonum Multiflorum Nutrient Shampoo. This is a herbal shampoo that contains lauryl polyether ammonium sulfate, ammonium lauryl sulfate, and components of medicinal plants. Effects of this mixture chemical product on Vigna radiata were studied. It was shown that at some concentrations, water solutions of this chemical product produced toxic effects on the plant seedlings. At a concentration of $0.5 \%$ and after the 48-96 $\mathrm{h}$ exposure, the shampoo produced toxic effects and caused a more than $50 \%$ inhibition of the root elongation. The new results are in full accord with the previous experiments conducted by the research group of S.A. Ostroumov at Lomonosov Moscow State University.
\end{abstract}

Keywords: plant science, phytotest, phytotoxicity, plant seedlings, aquatic toxicology, surfactants, bioassay, environmental hazards, ecotoxicology, Vigna radiata.

Sažetak: Prikazani su rezultati istraživanja uticaja hemijskog proizvoda koji sadrži sintetičke tenzide na sadnice biljaka. Hemijski proizvod koji je proučavan bio je šampon proizveden u Kini, odnosno Ginger Polygonum Multiflorum Nutrient šampon. Ovo je biljni šampon koji sadrži lauril polieter amonijum sulfat, amonijum lauril sulfat i komponente lekovitih biljaka. Proučavani su učinci ovog hemijskog proizvoda na Vigna radiata. Pokazano je da su u nekim koncentracijama vodeni rastvori ovog hemijskog proizvoda imali toksične učinke na sadnice biljaka. U koncentraciji od 0,5\% i nakon izloženosti od 48-96 sati, šampon je imao toksične učinke i uzrokovao više od $50 \%$ inhibicije produženja korena. Novi rezultati u potpunosti su u skladu s prethodnim eksperimentima koje je obavila istraživačka grupa S.A. Ostroumova na Moskovskom državnom univerzitetu Lomonosov.

Ključne riječi: botanika, fitotest, fitotoksičnost, sadnice biljaka, vodena toksikologija, tenzidi, biološki test, opasnosti za životnu sredinu, ekotoksikologija, Vigna radiata.

e-mail: ar55@yandex.ru (S.A. Ostroumov) 


\section{INTRODUCTION}

In several previous publications, results of the bioassay of synthetic surfactants and surfactantcontaining chemical products were reported and facts about their phytotoxicity were discovered (Cai, Ostroumov, 2020, 2020a; Goryunova, Ostroumov, 1986; Ostroumov, Khoroshilov, 1992; Nagel et al., 1987; Ostroumov, Semykina, 1991; Maximov et al., 1988, 1988a; Ostroumov, 1990, 2001, 2004, 2006; Ostroumov, Golovko, 1992; Ostroumov et al., 1995; Lazareva, Ostroumov, 2009; Ostroumov, Solomonova, 2013; Ostroumov, Kotelevtsev, 2015, 2015a; Solomonova, Ostroumov, 2007; Poklonov et al., 2012). The concentrations of detergents and surfactants in water which produced toxic effects on a number of biological species were determined. Phytotesting approaches were used to characterize toxicity and environmental hazards from detergents.

Recently these studies were continued using detergents and biological species Lens culinaris and Vigna radiata for bioassays (e.g. Cai, Ostroumov, 2020, 2020a; Poklonov et al., 2012). It should be noted that surfactants and detergents are membranotropic chemical ecotoxicants. The molecular mechanisms of biological effects of them include interaction with biological membranes (Ostroumov, 2001, 2006).

The goal of this work was to study a herbal shampoo using a bioassay on Vigna radiata. The hypothesis to test was that the herbal shampoo may produce a toxic effect on the higher plant Vigna radiata.

\section{MATERIALS AND METHODS}

The chemical product that was tested in this work was a Chinese herbal shampoo, namely, Ginger Polygonum Multiflorum Nutrient Shampoo. It was manufactured by BAWANG International (Group) Holding Co., Ltd (Guangzhou, China). The nontransparent liquid shampoo appears brown color. The chemical composition of this commercial shampoo included the components: lauryl polyether ammonium sulfate, ammonium lauryl sulfate, cocamidopropyl betaine, cocamide MEA, glycol distearate, PDMS (polydimethylsiloxane), fragran$\mathrm{ce}$, sodium chloride, piroctone olamine, polyquaternium-47, polyquaternium-10, DMDM hydantoin, panthenol, EDTA-Na2, methylparaben, zingiber officinal (a type of extract from ginger roots), polygonum multiflorum (a Chinese medicine), and water.

The method was described in detail in the monographs (Ostroumov, 2001, 2006) and our articles (Cai, Ostroumov, 2020, 2020a; Ostroumov, 1990). The seeds were put in Petri dishes. The tested water solutions of the chemical studied were added to the Petri dishes. The quantitative parameters of the seedling growth were measured and the average values and standard errors were calculated. Statistical data analysis was performed using Microsoft Excel 2019 Program.

Number of seeds was 30 per Petri dish. For each concentration, there were three Petri dishes, each with 30 seeds. As a result, each concentration was tested with 90 seeds in toto.

The volume of the shampoo solution added to each Petri dish was $20 \mathrm{~mL}$.

The isometric volume $(20 \mathrm{~mL})$ of ultrapure water was used as the control. The ultrapure water was obtained using Heal Force Water Purification System (Canrex Analytic Instrument Co., Ltd, Shanghai, China).

Temperature of the incubation of the Petri dishes was $25.0 \pm 1.0^{\circ} \mathrm{C}$.

Seed germination index (SGI) and root length index (RLI) that exemplified phytotoxicity index were described in Eq. (1) and (2),

$$
\begin{aligned}
& S G I=\frac{N_{T}(i)-N_{C}}{N_{C}} \\
& R L I=\frac{L_{T}(i)-L_{C}}{L_{C}}
\end{aligned}
$$

where $\mathrm{N}_{T}(\mathrm{i})$ and $\mathrm{N}_{C}$ represent the number of germinated seeds in test (i) and in control, and $L_{T}(i)$ and $L_{c}$ refer to the mean root length in test (i) and in control. Based on the published empirical value of risk assessment (Bagur-González et al., 2011; Mtisi, Gwenzi, 2019), the phytotoxicity can be sorted into four classes such as:

(1) slight $(-0.25 \leq \mathrm{SGI}$ or $\mathrm{RLI}<0)$,

(2) moderate $(-0.5 \leq \mathrm{SGI}$ or $\mathrm{RLI}<-0.25)$,

(3) high $(-0.75 \leq \mathrm{SGI}$ or RLI $<-0.5)$, and

(4) extreme toxicity $(-1 \leq \mathrm{SGI}$ or RLI $<-0.75)$.

Other details of the method of the experiments were described in (Ostroumov, 2001, 2006).

\section{RESULTS AND DISCUSSION}

The main results are presented in Tables 1 and 2. In Table 1, the average lengths of the roots of the seedlings after $48 \mathrm{~h}$ exposure are presented, as well as the standard errors. In Table 2, the analogous data for the seedlings after $96 \mathrm{~h}$ exposure are given. 
It is seen from Table 1 and 2 that the increased concentrations of the chemical tested (Ginger Polygonum Multiflorum Nutrient Shampoo) produced increased toxicity on the biological species used, namely, the higher plant Vigna radiata.

The increased concentrations induced a decrease in the root length.

The largest concentration tested (5\%) produced the most pronounced toxic effect, both at $48 \mathrm{~h}$ and $96 \mathrm{~h}$ incubation time periods.

The interpretation of the data obtained is presented in Table 3.

The obtained results are in accord with the previous results of research projects conducted in the group of S.A. Ostroumov at Lomonosov Moscow State University (Cai, Ostroumov, 2020, 2020a; Goryunova, Ostroumov, 1986; Ostroumov, Khoroshilov, 1992; Nagel et al., 1987; Ostroumov, Semykina, 1991; Maximov et al., 1988, 1988a; Ostroumov, 1990, 2001, 2004, 2006; Ostroumov, Golovko, 1992; Ostroumov et al., 1995; Lazareva, Ostroumov, 2009; Ostroumov, Solomonova, 2013; Ostroumov, Kotelevtsev, 2015, 2015a; Solomo- nova, Ostroumov, 2007; Poklonov et al., 2012). Previous data obtained in this group demonstrated phytotoxicity of surfactants and several surfactantcontaining chemical mixtures to higher plants, both terrestrial plants (Cai, Ostroumov, 2020, 2020a; Goryunova, Ostroumov, 1986; Ostroumov, Khoroshilov, 1992; Nagel et al., 1987; Ostroumov, Semykina, 1991; Maximov et al., 1988, 1988a; Ostroumov, 1990, 2001, 2004, 2006; Ostroumov, Golovko, 1992; Ostroumov et al., 1995; Poklonov et al., 2012) and aquatic macrophytes (Ostroumov, Solomonova, 2013; Solomonova, Ostroumov, 2007; Ostroumov, 2004, 2006).

The new results obtained in the experiments described in this article discovered a new relevant example of toxicity of the chemical mixtures that contain membranotropic substances (synthetic surfactants). At concentrations $0.5 \%$ and more, the chemical product, namely, Ginger Polygonum Multiflorum Nutrient Shampoo, produced pronounced toxic effects of , which means that the hypothesis formulated at the beginning of this article was correct and confirmed.

Table 1 - The mung beans (Vigna radiata) test results for $48 \mathrm{~h}$ exposure to various concentrations of the water solution of Chinese herbal shampoo (namely, Ginger Polygonum Multiflorum Nutrient Shampoo, $20 \mathrm{~mL})$ at $25.0 \pm 1.0^{\circ} \mathrm{C}$

\begin{tabular}{|l|c|c|c|c|c|}
\hline $\begin{array}{l}\text { Concentration } \\
(\%)\end{array}$ & $0.0 \%$ (control) & $0.1 \%$ & $0.5 \%$ & $1.0 \%$ & $5.0 \%$ \\
\hline $\begin{array}{l}\text { Average length } \\
\text { of root (mm) }\end{array}$ & 19.68 & 22.63 & 13.51 & 7.15 & 0.27 \\
\hline Standard error & 0.64 & 0.92 & 0.80 & 0.61 & 0.13 \\
\hline SGI & 0.00 & -0.01 & -0.04 & -0.16 & -0.93 \\
\hline RLI & 0.00 & 0.15 & -0.31 & -0.64 & -0.99 \\
\hline
\end{tabular}

Note to Table 1. The numbers of seedlings, the roots of which were calculated to obtain the mean (average) length of roots were: $n=89$ for $0.0 \%$ (control); $n=88$ for $0.1 \%$ shampoo solution, $n=85$ for $0.5 \%$, and $n=75$ for $1.0, n=6$ at $5.0 \%$ shampoo solution.

Table 2 - The mung beans (Vigna radiata) tests for the $96 \mathrm{~h}$ exposure to various concentrations of the water solution of the shampoo (namely, Ginger Polygonum Multiflorum Nutrient Shampoo, $20 \mathrm{~mL}$ ) at $25.0 \pm 1.0^{\circ} \mathrm{C}$

\begin{tabular}{|l|c|c|c|c|c|}
\hline $\begin{array}{l}\text { Concentration } \\
(\%)\end{array}$ & $0.0 \%$ (control) & $0.1 \%$ & $0.5 \%$ & $1.0 \%$ & $5.0 \%$ \\
\hline $\begin{array}{l}\text { Average length } \\
\text { of root (mm) }\end{array}$ & 58.47 & 50.48 & 22.36 & 8.19 & 0.35 \\
\hline Standard error & 1.70 & 2.24 & 1.38 & 0.66 & 0.13 \\
\hline SGI & 0.00 & -0.01 & -0.03 & -0.08 & -0.91 \\
\hline RLI & 0.00 & -0.14 & -0.62 & -0.86 & -0.99 \\
\hline
\end{tabular}


Table 3 - Interpretation of the data obtained in our experiments after 96h exposure of the seedlings of Vigna radiata to various concentrations of the chemical product tested, namely, Ginger Polygonum Multiflorum Nutrient Shampoo (see Table 2)

\begin{tabular}{|l|c|c|}
\hline $\begin{array}{l}\text { Concentration (\%) of the } \\
\text { chemical product tested }\end{array}$ & $\begin{array}{c}\text { Interpretation of the results of } \\
\text { the phytotest in this study }\end{array}$ & Comments \\
\hline 0 & No toxicity & No inhibition of growth \\
\hline 0.1 & Slight toxic effect & A slight inhibition of growth \\
\hline 0.5 & A pronounced toxicity & Inhibition of growth almost $50 \%$ \\
\hline 1.0 & Strong toxicity & $\begin{array}{c}\text { Inhibition of growth more than } \\
50 \%\end{array}$ \\
\hline 5.0 & Lethal effect & No root growth observed; \\
\hline
\end{tabular}

It worth mentioning that the chemical mixture which was tested in this research project, namely, the herbal shampoo (namely, Ginger Polygonum Multiflorum Nutrient Shampoo), is a broadly used body-care product.

The chemical products of this type are manufactured and sold in large quantities. The discharge of these chemicals into aquatic bodies and streams is substantial. The aquatic pollution with these chemicals is significant. Therefore, the potential environmental impact of the water pollution with these type of chemicals is of increasing concern.

As for the molecular mechanisms of biological effect of this mixture product and its constituents, the goal of this study did not include these issues. However it is a well-documented fact that synthetic surfactants and detergents can intercalate into lipid bilayer or other parts of biomembranes and by doing so may change relevant structural and functional parameters of the biomembranes (Ostroumov, 2001, 2006). As a result there are serious reasons to consider these chemicals membranotropic agents.

The environmental and ecotoxicological considerations associated with water pollution with surfactants and surfactant-containing chemical products were analyzed in detail in the previous publications, namely, the monographs (Ostroumov, $2001,2006)$. The new results presented here provide a further substantiation to the main conclusions made in these monographs.

\section{CONCLUSION}

- The phytotest with Vigna radiata was successfully applied to detection and quantification of potential toxicity of a shampoo.

- The hypothesis formulated at the beginning of this article was confirmed.

- It was found the the phytotest with Vigna radiata is an effective method to quantitat- ively study biological (phytotoxic) effects of the shampoo.

- It was discovered that at certain concentrations $(0.5 \%$ and more) and time exposures (48 $\mathrm{h}$ and more) the chemical tested, namely, the Chinese herbal shampoo, Ginger Polygonum Multiflorum Nutrient Shampoo, produced toxic effects on the plant seedlings (Vigna radiata).

- There are extracts of medicinal plants in the herbal shampoo. However, there presence does not nullify the toxic effects from this shampoo.

\section{Acknowledgments}

This work was funded by Lomonosov Moscow State University (Russian Federation) and Shenzhen MSU-BIT University (People's Republic of China). For the financial aid, the Shenzhen and Guangdong province governments are also appreciated.

\section{REFERENCES}

[1] Bagur-González, M.G., Estepa-Molina, C., Martín-Peinado, F., Morales-Ruano, S. (2011). Toxicity assessment using Lactuca sativa $L$. bioassay of the metal(loid)s $\mathrm{As}, \mathrm{Cu}, \mathrm{Mn}, \mathrm{Pb}$ and $\mathrm{Zn}$ in soluble-in-water saturated soil extracts from an abandoned mining site. Journal of Soils and Sediments, 11, 281-289. DOI https://doi.org/10.1007/s11368-010-0285-4.

[2] Cai, X., Ostroumov, S.A. (2020). Bioassay of "Tide Color" powder laundry detergent using Lens culinaris. Ecologica, 27(99), 395-400.

[3] Cai, X., Ostroumov, S.A. (2020a). Discovery of detergent toxicity using non-animal bioassay. Biogeochemical Innovations, Vol. 2, 216219.

[4] Goryunova, S.V., Ostroumov, S.A. (1986). Effects of an anionic detergent on green algae 
and some angiosperms. Biological Sciences, No. 7, 84-86.

[5] Lazareva, E.V., Ostroumov, S.A. (2009). Accelerating the reduction of the concentration of surface-active substances in water microcosms in the presence of plants: Innovations for phytotechnology. Doklady Akademii Nauk, 425, 843-845.

[6] Maximov, V.N., Nagel, H., Kovaleva, T.N., Ostroumov, S.A. (1988). Biotesting of water polluted by sulfonol. Water Resources, No. 1, 165-168.

[7] Maximov, V.N., Nagel, H., Ostroumov, S.A. (1988a). Biotesting waters containing a surfactant (sulfonol) and DNOC. Hydrobiological Journal, 24, 54-55.

[8] Mtisi, M., Gwenzi, W. (2019). Evaluation of the phytotoxicity of coal ash on lettuce (Lactuca sativa L.) germination, growth and metal uptake. Ecotoxicology and Environmental Safety, 170, 750-762. DOI:

10.1016/j.ecoenv.2018.12.047.

[9] Nagel, H., Ostroumov, S.A., Maximov, V.N. (1987). Inhibition of elongation of seedlings of buckwheat under the effect of sodium dodecylsulphate. Biological Sciences, No.12, 81-84.

[10] Ostroumov, S.A. (1990). Certain Aspects of Evaluating Biological Activity of Xenobiotics. Vestnik MGU, Series 16, Biologiya, 2, 27-34.

[11] Ostroumov, S. A. (2001). Biological Effects of Action of Surfactants on Organisms, MAKSPress, Moscow, p. 334. (in Russian).

[12] Ostroumov, S.A. (2004). On the Biotic Selfpurification of Aquatic Ecosystems: Elements of the Theory. Doklady Biological Sciences, Vol. 396, 206-211. DOI:

https://doi.org/10.1023/B:DOBS.0000033278. 12858.12

[13] Ostroumov, S.A. (2006). Biological effects of surfactants. CRC Press.

[14] Ostroumov, S.A., Golovko, A.E. (1992). Biotesting of surfactant (sulphonol) toxicity using rice seedings as a test-object. Hydrobiological Journal (Kiev), Vol. 28, 72-75.
[15] Ostroumov, S. A., Khoroshilov, V. S. (1992). Biological activity of waters polluted with a liquid surfactant-containing detergent. Izvestiya Rossiiskoi Akademii Nauk, Seriya Biologicheskaya, No. 3, 452-458.

[16] Ostroumov, S.A., Kotelevtsev, S.V. (2015), Using agricultural plants in order to access toxicity of chemical pollutants to control pollution of the environment: informational biotechnology. International Symposium of ISB- INMA TEH. Agricultural and Mechanical Engineering, Bucharest, Romania, 29-31 October 2015, (pp. 405-408), INMA Bucharest.

[17] Ostroumov, S.A., Kotelevtsev, S.V. (2015a). Assessing environmental hazards of chemicals: the efficient method with higher plants. Black Sea Scientific Journal of Academic Research, Vol. 26, p.8.

[18] Ostroumov, S.A., Samoilenko, L.S., Telitchenko, M.M. (1995). Studies on some aspects of ecotoxicology and biochemical ecology of surfactants. Biodeterioration and Biodegradation, Vol. 9, 641-641.

[19] Ostroumov, S.A., Semykina, N.A. (1991). Response of seedlings of macrophytes to water pollution by macro-molecular surfactant. Ecology (Russia), No. 4, 83-85. (in Russian)

[20] Ostroumov, S.A., Solomonova, E.A. (2013). Phytotoxicity of a surfactant-containing product towards macrophytes. Russian Journal of General Chemistry, 83, 2614-2617;

[21] Poklonov, V.A., Kotelevtsev, S.V., Ostroumov, S.A. (2012). On the effect of detergents on Vigna radiata and Lens culinaris under biotest conditions. Toxicological Bulletin, No. 5, 4953.

[22] Solomonova, E. A., Ostroumov, S. A. (2007). Tolerance of an Aquatic Macrophyte Potamogeton crispus L. to Sodium Dodecyl Sulphate. Moscow University Biological Sciences Bulletin, Vol. 62, 176-179. DOI: 10.3103/S0096392507040074. 